\title{
NOTE ON THE NITROGEN CONTENT OF MALIGNANT TUMOURS IN MAN. ${ }^{1}$
}

\author{
By R. A. Chisolm, Greville Research Student.
}

From the Pathological Department, Guy's Hospital, London, S.E.

As the result of a study of the nitrogenous metabolism of rats bearing transplanted sarcomata, Cramer and Pringle $\left(1910^{1}\right)$ concluded that "less nitrogen is needed to build up a given weight of tumour tissue than is necessary to build up an equal weight of the somatic tissues of the host." From this they drew the inference that tumour tissue should contain less nitrogen than the somatic tissues, and in a second paper published at the same time they showed that this was actually the case. As anything is of interest that bears on the relations between transplanted tumours in animals and spontaneous tumours in man, I have estimated by Kjeldahl's method the nitrogen in ten cases of various types of human tumour obtained from the post-mortem room, together with the nitrogen in the heart, liver, kidney, and muscle of the host, and the results are shown in the two following tables. The method adopted by Cramer and Pringle, who estimated both the fraction of the nitrogen which was coagulable by alcohol and the total nitrogen in the same piece of tissue, did not allow them to express their results as a percentage of the dried tissue weight, but only of the fresh tissue. For purposes of comparison, therefore, Table I. shows the nitrogen expressed as a percentage of the fresh tissue weight, while Table II. gives the results in percentages of the dried weight.

As will be seen from Table I., the nitrogen content considered as a percentage of the fresh tissue is in all cases lower in the tumour than in the somatic tissues of the host, with the exception of the kidney, which contains a larger proportion of water than the heart, liver, or muscle. Table II., however, shows that tive nitrogen, expressed as a percentage of the dried tissue weight, is only noticeably smaller in the tumour than in the somatic tissues in the first four cases; in Cases 5 and 6 it is slightly lower; while in the last four cases there is no difference of moment. Why the percentage should be lower in some cases than in others it is difficult to say. Beebe (1904-5 ${ }^{2}$, in his study of the inorganic constituents of human tumours

\footnotetext{
${ }^{1}$ Received February 21, 1913.
} 
found that tumours with a low percentage of nitrogen contained a higher proportion of ether-soluble substances than those with a high percentage of nitrogen, and that may have been the case with my

Table I.

\begin{tabular}{|c|c|c|c|c|c|c|c|}
\hline & \multicolumn{6}{|c|}{$\begin{array}{l}\text { Nitrogen as Percentage of Fresh } \\
\text { Tissue in }\end{array}$} & \\
\hline & 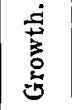 & Metastasis. & 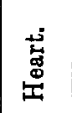 & 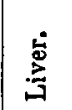 & 宫 & $\frac{\stackrel{0}{J}}{\stackrel{\Xi}{g}}$ & \\
\hline $\begin{array}{l}\text { 1. Sarcoma of ileum } \\
\text { 2. Sarcoma of duo- } \\
\text { denum }\end{array}$ & $\begin{array}{l}1 \cdot 66 \\
1 \cdot 84\end{array}$ & $\cdots$ & $\begin{array}{l}2 \cdot 10 \\
2 \cdot 26\end{array}$ & $\begin{array}{l}2 \cdot 62 \\
2 \cdot 45\end{array}$ & $\begin{array}{l}2 \cdot 20 \\
1 \cdot 91\end{array}$ & $\begin{array}{l}2 \cdot 86 \\
2 \cdot 95\end{array}$ & 1.87 (normal duo. \\
\hline 3. Scirrhus of breast & $2 \cdot 52$ & $\cdot$ & $2 \cdot 80$ & $3 \cdot 09$ & $1 \cdot 76$ & $2 \cdot 77$ & ... \\
\hline 4. Scirrhus of rectum & 1.86 & $\cdots$ & $2 \cdot 25$ & $2 \cdot 11$ & $1 \cdot 97$ & $2 \cdot 67$ & $\cdots$ \\
\hline $\begin{array}{l}\text { 5. Carcinoma of pan- } \\
\text { creas }\end{array}$ & $2 \cdot 30$ & 1.86 (liver) & $2 \cdot 77$ & $2 \cdot 87$ & $2 \cdot 48$ & $2 \cdot 99$ & ... \\
\hline $\begin{array}{l}\text { 6. Carcinoma of } \\
\text { stomach }\end{array}$ & 1.90 & $\begin{array}{l}2 \cdot 12 \text { (liver) } \\
1.84 \text { (gland) }\end{array}$ & $2 \cdot 41$ & $2 \cdot 56$ & 1.88 & $2 \cdot 90$ & $1 \cdot 97$ (normal stomach). \\
\hline 7. Carcinoma of colon & $1 \cdot 74$ & 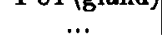 & $2 \cdot 58$ & $2 \cdot 41$ & $2 \cdot 41$ & $2 \cdot 95$ & 1.85 (normal colon). \\
\hline $\begin{array}{l}\text { 8. Caroinoma of } \\
\text { bronchus }\end{array}$ & $2 \cdot 17$ & & $2 \cdot 42$ & $2 \cdot 92$ & 1.82 & $2 \cdot 78$ & \\
\hline 9. Carcinoma of & 1.94 & $2 \cdot 05$ (lung) & $2 \cdot 39$ & $2 \cdot 60$ & $2 \cdot 29$ & 3.02 & $1 \cdot 60$ (normal lung). \\
\hline 10. Lymphadenoma . & 1.89 & $\ldots$ & $2 \cdot 40$ & $2 \cdot 60$ & $1 \cdot 89$ & $2 \cdot 88$ & $\ldots$ \\
\hline
\end{tabular}

TABLE II.

\begin{tabular}{|c|c|c|c|c|c|c|c|}
\hline & \multicolumn{6}{|c|}{$\begin{array}{l}\text { Nitrogen as Percentage of Dried } \\
\text { Tissue in }\end{array}$} & \\
\hline & 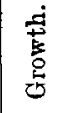 & Metastasis. & $\begin{array}{l}\text { 莺 } \\
\text { 出 }\end{array}$ & 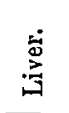 & 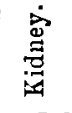 & 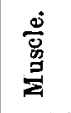 & \\
\hline 1. Sarcoma of ileum & $5 \cdot 5$ & ... & $10 \cdot 9$ & $11 \cdot 8$ & $13 \cdot 9$ & $13 \cdot 9$ & \\
\hline $\begin{array}{l}\text { 2. Sarcoma of duo- } \\
\text { denum }\end{array}$ & $9 \cdot 3$ & ... & $11 \cdot 2$ & $11 \cdot 6$ & $11 \cdot 5$ & $13 \cdot 3$ & $\begin{array}{l}11.9 \text { (normal dno- } \\
\text { denum). }\end{array}$ \\
\hline 3. Scirrhus of breast & $5 \cdot 95$ & . & $12 \cdot 5$ & $12 \cdot 7$ & $12 \cdot 4$ & $11 \cdot 0$ & $\ldots$ \\
\hline 4. Scirrhus of rectum & $7 \cdot 6$ & & $11 \cdot 7$ & $11 \cdot 3$ & $12 \cdot 2$ & $14 \cdot 0$ & $\ldots$ \\
\hline $\begin{array}{l}\text { 5. Carcinoma of pan- } \\
\text { ereas }\end{array}$ & $11 \cdot 4$ & $11 \cdot 5$ (liver) & $13 \cdot 0$ & $12 \cdot 3$ & $12 \cdot 8$ & $11 \cdot 9$ & $\cdots$ \\
\hline $\begin{array}{l}\text { 6. Carcinoma of } \\
\text { stomach }\end{array}$ & $11 \cdot 9$ & $\begin{array}{l}11 \cdot 9 \text { (gland) } \\
12 \cdot 2 \text { (liver) }\end{array}$ & $12 \cdot 2$ & $12 \cdot 1$ & $11 \cdot 8$ & $14 \cdot 5$ & $13 \cdot 6$ (normal stomach). \\
\hline 7. Cercinoma of colon & $12 \cdot 5$ & $\ldots$ & $12 \cdot 0$ & $11 \cdot 7$ & $11 \cdot 6$ & $12 \cdot 3$ & $12 \cdot 5$ (normal colon). \\
\hline $\begin{array}{l}\text { 8. Carcinom of } \\
\text { bronchus }\end{array}$ & $12 \cdot 7$ & $\cdots$ & $12 \cdot 9$ & $12 \cdot 2$ & $12 \cdot 1$ & $14 \cdot 1$ & $\cdots$ \\
\hline $\begin{array}{l}\text { 9. Carcin om a of } \\
\text { bronchus }\end{array}$ & $12 \cdot 9$ & $12 \cdot 8$ (lung) & $10 \cdot 8$ & $12 \cdot 4$ & $12 \cdot 3$ & $14 \cdot 3$ & 12.5 (normal lung). \\
\hline 10. Lymphadenoma. & $12 \cdot 9$ & ... & $12 \cdot 5$ & $11 \cdot 5$ & $12 \cdot 2$ & $14 \cdot 0$ & ... \\
\hline
\end{tabular}

tumours. Though it might be expected that rapidly growing tumours would contain less nitrogen than those that grow slowly, this is not the case; for, as far as it is possible to estimate the rate of growth of 41 -JL. OF PATH, - vOL. XVII. 
tumours in the thorax and abdomen, No. 1, with a small nitrogen percentage, and Nos. 8 and 9 , with a high proportion, were all rapidly growing tumours, while Nos. 3 and 4 , in both of which the percentage of nitrogen was low, grew slowly, indeed No. 3 was probably the slowest in growth of all the tumours in the series. Nor is the explanation to be found in the different proportions of necrotic and actively-living cells, for, while accurate measurement of the amount of necrosis is difficult, it was obvious that the amount bore no relation to the percentage of nitrogen.

Two other points of interest may be noted. In four cases (Nos. $2,6,7$, and 9) an estimation was made of the percentage of nitrogen in the tissue from which the tumour grew. It will be seen that in two cases (Nos. 2 and 6) the tumour contained a nitrogen percentage which was well below that of the mother tissue, while in two cases the proportion was practically the same in both. The second point is the relation between the original tumour and the metastases. Beebe $\left(1905^{3}\right)$ has given reasons for thinking that while the mother tumour and its metastases present the same histological picture, there may be chemical differences between the two. It will be seen, however, that in the four cases when analyses were made of the tumour and its metastases the resemblance between them is very close.

Cramer and Pringle found that the percentage of nitrogen which was coagulable with alcohol was less in the tumour than in the somatic tissues. I therefore estimated this percentage in portions of tissues dried by Schryver's (1906 ${ }^{4}$ sodium sulphate method. I found, however, that post-mortem autolytic changes introduced a factor which rendered the results so variable that no conclusions could be drawn from them, so they are not given here.

A number of estimations were also made of the nitrogen percentage in the heart, liver, kidney, and muscle of normal healthy adults who had died from accidents, but they showed no difference as compared with the same tissues in persons dying of malignant disease.

\section{REFERENCES.}

1. Cramer and Pringle. . Proc. Roy. Soc. London, Sec. B, 1910, vol. lxxxii. p. 307.

2. Beebe . . . . . . . Am. Journ. Physiol., 1904-5, vol. xii. p. 167.

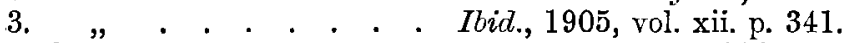

4. ScHRYver . . . . . . Biochem. Journ., 1906, vol. i. p. 123. 